DOI: 10.2478/v10014-008-0005-6

Agrovoc descriptors: helianthus annuus, varieties, height, seeds, crop yield, proximate composition, fats, oleic acid, oils, rotational cropping, plant introduction

Agris category codes: F01, F50, F60

University of Ljubljana

Biotechnical Faculty

Department of agriculture

COBISS Code 1.01

\title{
Some economically important properties of sunflower cultivars (Helianthus annuus L.) in the field trials performed at Biotechnical faculty
}

\author{
Darja KOCJAN AČKO ${ }^{1}$
}

Received: November $8^{\text {th }}, 2007$; accepted: April 28, 2008

Delo je prispelo 8. novembra 2007; sprejeto 28. aprila 2008

\begin{abstract}
The basic parameter of re-introduction of this crop into the crop rotation in Slovenia is testing and trials of sunflower cultivars (Helianthus annuus L.), that could be suitable for the growing conditions in Slovenia, for the purpose of organic production and for the production of healthy food for consumers. On the experimental field at Biotechnical Faculty, in the period from 2002 to 2006, we were testing certain economically significant properties of five sunflower cultivars: Kernal, Kongo, Delija, Goleador and Iregi szürke csíkos. Seeds were sown by hand to the parcel in the size of $3 \mathrm{~m} \times 11.8 \mathrm{~m}$. Under the growing conditions in central Slovenia the genetic potential of hybrids for the production above $4 \mathrm{t}$ of seed/ha was almost reached and closely approached by the hybrids Kongo and Kernal with average yields $3.5 \mathrm{t} / \mathrm{ha}$ and $3.3 \mathrm{t} / \mathrm{ha}$. Yields of Delija and Goleador hybrids were about 1 to 1.2 tons lower, but mutually comparable. The lowest yield (1.6 t/ha) was given by Iregi szurke csikos variety, which is mostly grown by the producers in Slovenia, mainly because it is used and sold as a bird feed. In the year 2003, the fat content in the seed obtained from the hybrids, reached from 38 to $42 \%$, for Iregi szurke csikos variety it was only $33 \%$, on the other side - in the year 2005 - the fat content in the seed obtained from the hybrids was higher, that is 39 to $45 \%$, and for the Iregi szurke csikos variety the average was the same as in the year 2003. The highest fat content in the seed was reached by highly oleic hybrid Goleador, that is $42 \%$ in the year 2003 and $45 \%$ in 2005; for this hybrid, during this two years of the trials the 78- to 79-percent content of oleic acid in the oil was a little lower than its genetic potential, which is above $80 \%$. Regarding the use of the crop - for the cold pressed oil - the most important cultivars are the highly oleic hybrid Goleador and semioleic Delija, and for the bird feed instead of the Iregi szurke csikos variety we could sow Kongo and Kernal hybrids, not only due to their higher yields, but also due to higher fat content. Experts can advise producers how they can increase their production of seeds and oil only on the basis of tested, high quality and accessible sunflower assortment.
\end{abstract}

Key words: sunflower, cultivars (hybrids, varieties), plant height, yield of seed, fat content of the seed, content of oleic acid in the oil

1 High. Educ. Lect., Ph.D., Biotehnical Faculty, Dept. Of Agronomy, Jamnikarjeva 101, SI-1111 Ljubljana, e-mail: darja.kocjan@bf.uni-lj.si 


\section{IZVLEČEK}

NEKATERE GOSPODARSKO POMEMBNE LASTNOSTI KULTIVARJEV SONČNICE (Helianthus annuus L.) V POLJSKIH POSKUSIH BIOTEHNIŠKE FAKULTETE

Preizkušanje kultivarjev sončnice (Helianthus annuus L.), ki bodo ustrezali rastnim razmeram v Sloveniji, potrebam sonaravne pridelave in potrošnikom zdrave hrane, je temelj ponovnega uvajanja te poljščine $v$ kolobar. Na poskusnem polju Biotehniške fakultete smo $v$ obdobju 2002 do 2006 preučevali nekatere gospodarsko pomembne lastnosti petih kultivarjev sončnice: Kernal, Kongo, Delija, Goleador in Iregi szürke csíkos. Seme smo posejali ročno na parcelo velikosti $3 \mathrm{~m}$ x 11,8 $\mathrm{m}$. Genskemu potencialu hibridov za pridelek nad $4 \mathrm{t}$ semena/ha sta se $\mathrm{v}$ rastnih razmerah osrednje Slovenije najbolj približala hibrida Kongo in Kernal s povprečnima pridelkoma 3,5 t/ha in 3,3 t/ha. Pridelek hibridov Delija in Goleador je bil za 1 do 1,2 toni manjši, vendar med seboj primerljiv. Najmanjši pridelek je dala sorta Iregi szurke csikos (1,6 t/ha), ki jo pridelovalci sončnice $v$ Sloveniji sejejo največ, ker je $v$ prodaji za krmo ptic. Vsebnost olja $v$ semenu v letu 2003 je bila pri hibridih od 38 do $42 \%$, pri sorti Iregi szurke csikos pa le $33 \%$, nasprotno pa je bila oljnatost semena v letu 2005 pri hibridih večja, to je 39 do $45 \%$, pri sorti Iregi szurke csikos pa približno enaka kot v letu 2003. Največjo vsebnost olja v semenu je imel visoko oleinski hibrid Goleador, in sicer $42 \%$ v letu 2003 in $45 \%$ v letu 2005; 78- do 79odstotna vsebnost oleinske kisline $v$ olju pa je bila $v$ obeh letih nekoliko manjša od njegovega genskega potenciala za to lastnost, ki je nad $80 \%$. Glede na namen uporabe pridelka sta za hladno stisnjeno olje najprimernejša visoko oleinski hibrid Goleador in pol oleinski Delija, za krmo ptic pa bi lahko namesto sorte Iregi szurke csikos sejali hibrida Kongo in Kernal, ne le zaradi večje rodnosti, ampak tudi zaradi večje vsebnosti maščob. Le na podlagi preizkušenega, kakovostnega in dostopnega sortimenta sončnice bodo lahko strokovnjaki svetovali pridelovalcem, tako, da bodo ti pridelali več semena in maščob.

Ključne besede: sončnica, kultivarji (hibridi, sorte), višina rastlin, pridelek semena, vsebnost maščob v semenu, vsebnost oleinske kisline $v$ olju

\section{INTRODUCTION}

With the average of 25 million hectares sown lands around the world, the sunflower (Helianthus annuus L.), is one of the main crops for the oil production, following soy, cotton and rape seed (FAO, 2007). In the first half of the 20th century the sunflower was a traditional crop in Slovenia, sown on 500 to 1000 hectares of lands (Sadar, 1951; Tajnšek, 1987). In the beginning of the 21 st century, when it is covering only few 10 hectares, it is more often used as a decoration on the borders of smaller fields and in the house gardens. (Kocjan Ačko, 1999). The sunflower seed is not used only for the industrial production of table oil or bio diesel, but also for the production of cold pressed table oil, husked seeds, roasted or fresh, that could be used whole or grounded for different foods. In Slovenia we import not only the raw sunflower oil for the food processing industry but also sunflower seeds for the bird feed. Our total needs are covered by annual import of approximately $600 \mathrm{t}$ (Jereb, 2004).

Since in Slovenia there are no local varieties of sunflower, we can choose among modern foreign cultivars, that are by their genetic composition the hybrids with best properties in the $F_{1}$ generation. Well appreciated and spread on two million hectares in the world are the hybrids coming from the Institute for Agriculture in Novi Sad (Inštitut za ratarstvo i povrtarstvo, Novi Sad). The main goals of sunflower selection are: the yield of seeds over $4 \mathrm{t} / \mathrm{ha}$, the husk share lower than $25 \%$, more than 50 - 
percent fat content in the seed, higher contents of fatty acids favourable for human health, mostly oleic acid which - in the oil of some hybrids - already reaches over 80-percent (Skorić, 1986).

In Slovenia, after 2004, we can sow any type of cultivar that is listed in the Common catalogue of crop cultivars and is registered in at least one member state of the European Union, but this does not guarantee the successful production under the growing conditions of our country (Kocjan Ačko, 2007). For the selection of a new cultivar, we usually use the descriptions of economically significant properties in commercial catalogues, but the advantage is in any case, in testing the cultivars under the growing conditions of the area where we are planning to organise the production.

The purpose of sunflower field trials is to determine economically significant characteristics of four new hybrids from Serbia - Kernal, Kongo, Delija and Goleador in comparison to an old Hungarian variety Iregi szurke csikos, which is due to the availability of the seed - mostly sown in Slovenia by amateurs and also by some producers. The purpose of the research is to replace the use of the Iregi szurke csikos variety seed with the hybrid certified seeds where we can expect not only the higher seed yield but also the higher fat production. Registration of two hybrids from Novi sad - Kernal and Goleador in Italy and registration of the Kongo hybrid in the Check Republic, Slovakia and Hungary is the reason, that after the year 2004, there was almost no introduction of sunflower cultivars in Slovenia.

Differences in the speed of growth and development, growing period, plant height, stability and quantity of seed yield, total fat content of the seeds and in the composition of oleic acids in the oil between the cultivars as well as between the different years of testing have been analysed with the use of descriptions of certain economically significant characteristics of these cultivars in commercial catalogues of seed producers (Table1).

Results of trials of the hybrids from Novi Sad on the experimental field of Biotechnical faculty will at least partly replace the official introduction and support the modernization of the assortment and re-introduction of sunflower into the crop rotation.

\section{MATERIAL AND METHODS}

\subsection{Field trial}

On the Biotechnical faculty experimental field, we have sown every year in the period from 2002 to 2006, the seed of five sunflower cultivars - four hybrids and the Iregi szurke csikos variety, which is being sold in Slovenia as bird feed (Table 1). 
Table 1: Economically significant properties of sunflower cultivars (Helianthus annuus L.): Kernal, Kongo, Delija, Goleador and Iregi szurke csikos from the seed catalogues

\begin{tabular}{|c|c|c|c|c|c|}
\hline Property & Kernal & Kongo & Delija & Goleador & $\begin{array}{l}\text { Iregi szurke } \\
\text { csikos }\end{array}$ \\
\hline $\begin{array}{l}\text { Colour of } \\
\text { the husk }\end{array}$ & Black & $\begin{array}{l}\text { black brown } \\
\text { with white } \\
\text { stripes }\end{array}$ & black & $\begin{array}{l}\text { dark grey to } \\
\text { black }\end{array}$ & $\begin{array}{l}\text { black grey } \\
\text { with white } \\
\text { stripes }\end{array}$ \\
\hline $\begin{array}{r}\text { Growing } \\
\text { period }\end{array}$ & $\begin{array}{l}110 \text { to } 115 \\
\text { days, } \\
\text { middle } \\
\text { early } \\
\text { hybrid }\end{array}$ & $\begin{array}{l}115 \text { to } 120 \\
\text { days, } \\
\text { middle } \\
\text { early } \\
\text { hybrid }\end{array}$ & $\begin{array}{l}100 \text { to } 115 \\
\text { days, } \\
\text { middle } \\
\text { early hybrid }\end{array}$ & $\begin{array}{l}100 \text { to } 110 \\
\text { days, } \\
\text { middle } \\
\text { early } \\
\text { hybrid }\end{array}$ & $\begin{array}{l}110 \text { to } 120 \\
\text { days, } \\
\text { middle early } \\
\text { hybrid }\end{array}$ \\
\hline $\begin{array}{c}\text { Average } \\
\text { height }\end{array}$ & $\begin{array}{l}175 \text { to } 180 \\
\mathrm{~cm}\end{array}$ & $\begin{array}{l}175 \text { to } 180 \\
\mathrm{~cm}\end{array}$ & $\begin{array}{l}160 \text { to } 180 \\
\mathrm{~cm}\end{array}$ & $\begin{array}{l}145 \text { to } 165 \\
\mathrm{~cm}\end{array}$ & $180 \mathrm{~cm}$ \\
\hline $\begin{array}{l}\text { Genetic } \\
\text { yield } \\
\text { potential }\end{array}$ & above 4 t/ha & above 4 t/ha & $4.5 \mathrm{t} / \mathrm{ha}$ & $4 \mathrm{t} / \mathrm{ha}$ & 1 to $2 \mathrm{t} / \mathrm{ha}$ \\
\hline $\begin{array}{l}\text { Fat content } \\
\text { in the } \\
\text { seed }\end{array}$ & 46 to $49 \%$ & 44 to $48 \%$ & 38 to $42 \%$ & 48 to $50 \%$ & 28 to $32 \%$ \\
\hline $\begin{array}{l}\text { The } \\
\text { contents } \\
\text { of oleic } \\
\text { acid in the } \\
\text { oil }\end{array}$ & 26 to $30 \%$ & 31 to $35 \%$ & $\begin{array}{l}\text { above } 40 \% \text { - } \\
\text { semi oleic } \\
\text { hybrid }\end{array}$ & $\begin{array}{l}\text { above } 80 \%- \\
\text { highly } \\
\text { oleic } \\
\text { hybrid }\end{array}$ & 26 to $30 \%$ \\
\hline $\begin{array}{l}\text { Use of } \\
\text { seeds }\end{array}$ & $\begin{array}{l}\text { eatable, for } \\
\quad \text { oil and } \\
\text { bird feed }\end{array}$ & $\begin{array}{l}\text { eatable, for } \\
\text { oil and } \\
\text { bird feed }\end{array}$ & $\begin{array}{l}\text { eatable, for } \\
\text { special } \\
\text { table oils } \\
\text { and bird } \\
\text { feed }\end{array}$ & $\begin{array}{l}\text { eatable, for } \\
\text { special } \\
\text { table oils }\end{array}$ & $\begin{array}{l}\text { eatable and } \\
\text { bird feed }\end{array}$ \\
\hline
\end{tabular}

Sowing was performed by hand, into rows, $50 \mathrm{~cm}$ distance between rows, $25 \mathrm{~cm}$ distance between seeds in the row; for each cultivar six rows have been sown on the parcel in the size of $3 \mathrm{~m} \times 11.6 \mathrm{~m}$, that is $34.8 \mathrm{~m}^{2}$. The sowing dates were Maj13th 2002, April 25th 2003, April 22nd 2004, April $26^{\text {th }} 2005$ and May $10^{\text {th }} 2006$.

Sunflowers have been sown within the crop rotation after the legumes (soy, low beans, peas) and in this way the need for the mineral nitrate was reduced to the single entry of $60 \mathrm{~kg} \mathrm{~N} / \mathrm{ha}$ (27-percent KAN). Weedyness was restricted with earthing-up twice, the first time when the plants were 10 to $20 \mathrm{~cm}$ high and the second time before the blooming. The sown hybrid seeds were certified and disinfected, and we have disinfected the seed of the Iregi szurke csikos variety ourselves. In the case of poor rising we have replaced the missing plants with additional sowing when the plants were $10 \mathrm{do} 20 \mathrm{~cm}$ high.

While monitoring the growth and development we have noted the following dates: beginning of blooming, full bloom, beginning of seed formation, wax ripeness and technological ripeness and we calculated the growing period. We also made estimations of lodging and pest attacks, mostly birds. Before the harvest we have measured the height of twenty randomly selected plants on individual parcel. Sunflower heads from the entire parcel were cut by hand for each cultivar separately at the time of technological ripeness of individual hybrid that is between September 2nd and 6th in 2002, August $10^{\text {th }}$ and $14^{\text {th }}$ in 2003 , September $2^{\text {nd }}$ and $7^{\text {th }}$ in 2004 , August $26^{\text {th }}$ and $31^{\text {st }}$ in 2005 and September $1^{\text {st }}$ and $6^{\text {th }}$ in 2006. Gathering of the heads for individual cultivar was completed within one day, with the exception of the Iregi szurke csikos variety, which was harvested gradually due to unequal ripeness. The heads were further dried in the drier at the temperature 40 to $45{ }^{\circ} \mathrm{C}$. After few days we hulled (trussed) seeds out of the heads and cleaned them with the use of trier from the dry parts of the plant, hulls and empty seeds and weighted them. Within the seed sample of individual cultivar we measured the humidity with the Pfeuffer he 50 humid meter and than we calculated the yield of seed using the prescribed 8percent humidity for the oil seed storing. For the easier comparison with the yields achieved in 
KOCJAN AČKO, D.: Some economically important properties of sunflower cultivars ...51

practice, we have calculated the yield from the experimental parcel in the size of $34,8 \mathrm{~m}^{2}$ to the data indicating this yield in tons per hectare.

\subsection{Weather conditions in the period from 2002 to 2006}

Analysis of average temperatures and precipitations in Ljubljana from April to September in the period from 2002 to 2006 showed deviations between the years (Pictures 1 and 2).

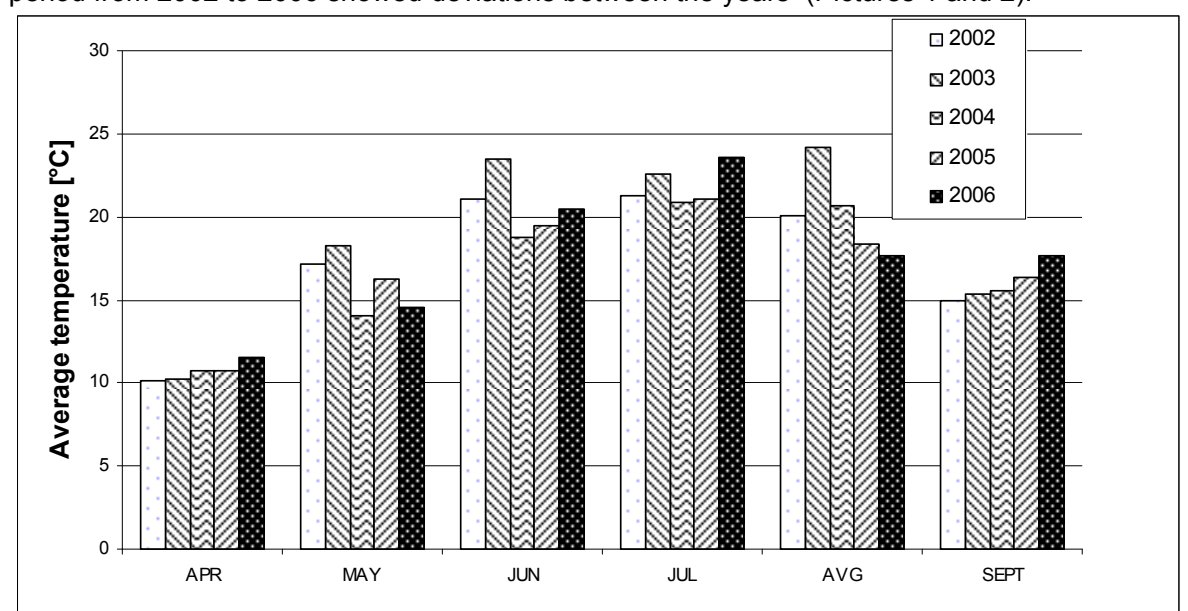

Picture 1: Average monthly temperature from April to September in Ljubljana in the period 2002 $-2006$

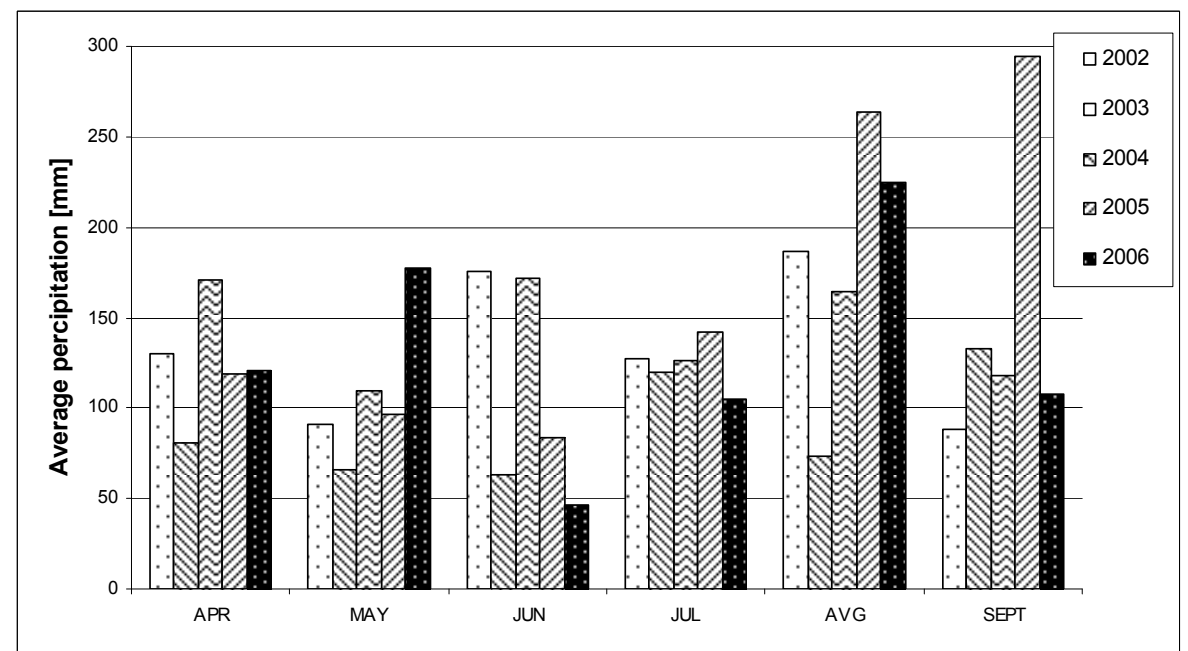

Picture 2: Average monthly quantity of precipitation from April to September in Ljubljana in the period $2002-2006$

\subsection{Oil pressing and fat analysis}

Hulled seeds of each individual cultivar (size of the sample $100 \mathrm{~g}$ ) were pressed and cold pressed oil was obtained. By the SIST ISO 5509 method we established the total fat content or the fat content of the seed, and by gas chromatography we have determined the oleic acids within the oil. Fats were analyzed twice; the first time from the sample of the 2003 yield seeds and the second time from the sample of 2005. 


\section{RESULTS AND DISCUSSION}

\subsection{Growth and development of sunflower cultivars in the period $2002-2006$}

While monitoring the growth and development of sunflower cultivars in the period from 2002 to 2006, we have noted the following dates: beginning of blooming, full bloom, beginning of seed formation, wax ripeness and technological ripeness (Table 2) and we calculated the growing period; this is the time from sowing to date of harvest in technological ripeness.

Table 2: Calendar monitoring of beginning of blooming (A), full bloom (B), wax ripeness (C) and technological ripeness (D) for sunflower cultivars (Helianthus annuus L.): Kernal, Kongo, Delija, Goleador and Iregi szurke csikos in the collection plantation, Biotechnical faculty, Ljubljana, 2002 to 2006.

A

\begin{tabular}{|l|c|c|c|c|c|}
\hline \multirow{2}{*}{ Cultivar } & \multicolumn{5}{|c|}{ Beginning of blooming } \\
\cline { 2 - 6 } & $\mathbf{2 0 0 2}$ & $\mathbf{2 0 0 3}$ & $\mathbf{2 0 0 4}$ & $\mathbf{2 0 0 5}$ & $\mathbf{2 0 0 6}$ \\
\hline Kernal & 19. July & 1. July & 26. July & 10. July & 16. July \\
\hline Kongo & 21. July & 4. July & 26. July & 12. July & 17. July \\
\hline Delija & 22. July & 5. July & 28. July & 14. July & 18. July \\
\hline Goleador & 22. July & 5. July & 28. July & 14. July & 18. July \\
\hline Iregi s. csikos & 21.- 23. July & 1. - 5. July & 26. - 30. July & 10. - 14. July & 17. - 20. July \\
\hline
\end{tabular}

B

\begin{tabular}{|l|c|c|c|c|c|}
\hline \multirow{2}{*}{ Cultivar } & \multicolumn{5}{|c|}{ Full bloom } \\
\cline { 2 - 6 } & $\mathbf{2 0 0 2}$ & $\mathbf{2 0 0 3}$ & $\mathbf{2 0 0 4}$ & $\mathbf{2 0 0 5}$ & $\mathbf{2 0 0 6}$ \\
\hline Kernal & 23. July & 8. July & 30. July & 17. July & 21. July \\
\hline Kongo & 27. July & 9. July & 30. July & 18. July & 22. July \\
\hline Delija & 29. July & 12. July & 31. July & 19. July & 22. July \\
\hline Goleador & 31. July & 12. July & 31. July & 19. July & 22. July \\
\hline Iregi s. csikos & 23. - 31. July & 8. - 12. July & 3. - 8. August & 18. - 20. July & 22. - 25. July \\
\hline
\end{tabular}

C

\begin{tabular}{|c|c|c|c|c|c|}
\hline \multirow[t]{2}{*}{ Cultivar } & \multicolumn{5}{|c|}{ Wax ripeness } \\
\hline & 2002 & 2003 & 2004 & 2005 & 2006 \\
\hline Kernal & 23. August & 1. August & 26. August & 19. August & 25. August \\
\hline Kongo & 24. August & 2. August & 28. August & 20. August & 26. August \\
\hline Delija & 26. August & 4. August & 28. August & 23. August & 26. August \\
\hline Goleador & 26. August & 4. August & 28. August & 23. August & 26. August \\
\hline
\end{tabular}

$\mathrm{D}$

\begin{tabular}{|l|c|c|c|c|c|}
\hline \multirow{2}{*}{ Cultivar } & \multicolumn{5}{|c|}{ Technological ripeness } \\
\cline { 2 - 6 } & Year 2002 & Year 2003 & Year 2004 & Year 2005 & Year 2006 \\
\hline Kernal & 2. September & 10. August & 2. September & 27. August & 1. September \\
\hline Kongo & 4. September & 12. August & 4. September & 29. August & 2. September \\
\hline Delija & 5. September & 14. August & 6. September & 30. August & 4. September \\
\hline Goleador & 5. September & 14. August & 6. September & 30. August & 4. September \\
\hline Iregi s. csikos & 4.-6.September & 10-14. August & 2.-7.September & 29-31. August & 1.- 7.September \\
\hline
\end{tabular}


We detected the differences in growing periods between cultivars (Table 3) and certain deviations from the data published in the catalogue (Table 1). Compared to the medium growing length of 100 to 120 days, the growing period of cultivars in Slovenia was longer for 10 to 20 days. Important oscillations in average dally temperature and higher and more frequent summer precipitations in 2004 are the reason that the growing period was prolonged to 133 or 138 days, respectively. The shortest growing period - 107 to 111 days was recorded in 2003, when the heat started already in June and together with low rainfalls quickened the ripening process.

During the testing period, the Kernal and Kongo hybrids proved to be the earliest, compared to those two, all other cultivars ripened later. While all hybrid plants equally passed over from one to another development stage, the main characteristics of the Iregi szurke csikos variety was the disproportionate blooming and ripening (Table 2).

Table 3: The growing period of sunflower cultivars (Helianthus annuus L.): Kernal, Kongo, Delija, Goleador and Iregi szurke csikos in collection plantation of Biotechnical faculty, Ljubljana, 2002 to 2006.

\begin{tabular}{|l|c|c|c|c|c|c|}
\hline \multirow{2}{*}{ Cultivar } & \multicolumn{5}{|c|}{ Length of the growth period (days) } & Growing \\
\cline { 2 - 7 } & $\mathbf{2 0 0 2}$ & $\mathbf{2 0 0 3}$ & $\mathbf{2 0 0 4}$ & $\mathbf{2 0 0 5}$ & $\mathbf{2 0 0 6}$ & $\begin{array}{c}\text { period } \\
\text { (days) }\end{array}$ \\
\hline Kernal & 111 & 107 & 133 & 123 & 114 & 107 to 135 \\
\hline Kongo & 113 & 109 & 135 & 125 & 115 & 109 to 135 \\
\hline Delija & 114 & 111 & 137 & 126 & 117 & 111 to 137 \\
\hline Goleador & 114 & 111 & 137 & 126 & 117 & 111 to 137 \\
\hline Iregi s. c. & 113 to 115 & 107 to 111 & 133 to 138 & 125 to 127 & 114 to 120 & 107 to 138 \\
\hline
\end{tabular}

With the use of plants in the protective crop on the borders of the collection plantation that were left on the field for approximately 10 days longer, after we harvested the experiment, we detected that the solid heads of the Goleador hybrid are less sensitive to bird attacks compared to the loos heads of Delija and Kernal hybrids, where it was easier for the birds to peck out the seeds and seeds were shedding on their own as well.

\subsection{Height of plants}

Regarding the height of the stalk, the Kernal and Kongo hybrids and the Iregi szurke csikos variety were among higher cultivars, which in the five year average amounted from 181 to $204 \mathrm{~cm}$ (Table 4). Compared to the high cultivars, the Delija and Goleador hybrids are lower with average height of $161 \mathrm{~cm}$ and $173 \mathrm{~cm}$, respectively. The Delija hybrid, which height was described in the catalogue at 160 to $180 \mathrm{~cm}$, was the lowest one in Slovenia during all five years; in 2004 it only grew $155 \mathrm{~cm}$ high. 
Table 4: Average height of twenty sample plants of sunflower cultivars (Helianthus annuus L.): Kernal, Kongo, Delija, Goleador and Iregi szurke csikos in collection plantation of Biotechnical Faculty, Ljubljana, 2002 to 2006.

\begin{tabular}{|l|c|c|c|c|c|c|}
\hline \multirow{2}{*}{ Cultivar } & \multicolumn{5}{|c|}{ Height (cm) } & $\begin{array}{l}\text { Average } \\
\text { height (cm) }\end{array}$ \\
\cline { 2 - 7 } & $\mathbf{2 0 0 2}$ & $\mathbf{2 0 0 3}$ & $\mathbf{2 0 0 4}$ & $\mathbf{2 0 0 5}$ & $\mathbf{2 0 0 6}$ & 204 \\
\hline Kernal & 214 & 210 & 190 & 205 & 200 & 187 \\
\hline Kongo & 190 & 182 & 180 & 195 & 185 & 161 \\
\hline Delija & 160 & 157 & 155 & 165 & 170 & 173 \\
\hline Goleador & 177 & 177 & 165 & 170 & 175 & 181 \\
\hline Iregi s. c. & 180 & 180 & 179 & 185 & 180 & 182 \\
\hline $\begin{array}{l}\text { Average } \\
\text { height } \\
\text { (cm) }\end{array}$ & 184 & 181 & 174 & 184 & 182 & \\
\hline
\end{tabular}

The most sensitive to lodging was the highest hybrid Kernal, which is, due to this characteristic, the least appropriate for machine harvesting. On the other side - the Delija and Goleador hybrids proved to be more stable and according their height the lower two from the hybrids and lower from the Iregi variety.

\subsection{Yield of the seed}

Under the growing conditions of central Slovenia, the genetic potential of the hybrids for over $4 \mathrm{t}$ seed/ha was most approached by the Kernal and Kongo hybrids (Picture 3). The biggest average yield of the seeds from all five years, calculated per hectare, was given by Kongo hybrid (3.5 t/ha), The yield of the Kernal hybrid was only for $200 \mathrm{~kg}$ lower. Yields reached by Delija $(2.5 \mathrm{t} / \mathrm{ha})$ in Goleador $(2.3 \mathrm{t} / \mathrm{ha})$ are, compared to the most fertile hybrids, lower for 1 to 1.2 tons per hectare and the lowest is the yield given by the Iregi szurke csikos variety $(1.6 \mathrm{t} / \mathrm{ha})$.

During the period from 2002 to 2006, the average yields of all cultivars were stable and in line with the highest ( $3 \mathrm{t} / \mathrm{ha}$ ), with the exception of the average yield in 2004, which was only $2.0 \mathrm{t} / \mathrm{ha}$. Humid summer in 2004 mostly harmed the two otherwise most fertile hybrids Kernal and Konga; compared to other years their yield for that year was approximately 1 ton lower. Calculation of four year average crop without the year 2004 revealed, that for every cultivar the four year average values are higher, that is 200 kilograms for the Kernal and Konga hybrid and 100 kilograms for the Delija and Goleador hybrid and Iregi szurke csikos variety. 


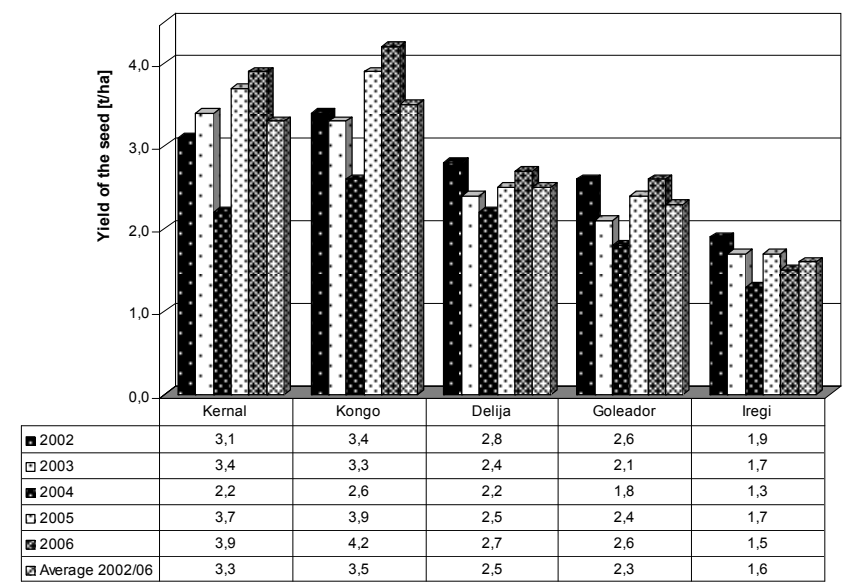

Picture 3: Yield (8-percent seed humidity) of the sunflower (Helianthus annuus L.) calculated in tons per hectare for the cultivars: Kernal, Kongo, Delija, Goleador and Iregi szurke csikos in collection plantation of Biotechnical Faculty, Ljubljana, 2002 to $2006 .$.

\subsection{Fat contents}

The content of fat in the seed or the total fat content analyzed in the year 2003 (Table 5) for all hybrids reached from 38 to $41 \%$, and for the Iregi szurke csikos variety only $33 \%$, on the other side the fattiness of the seed in the 2005 was higher (Table 6) for all hybrids, that is 39 to $45 \%$, and for the Iregi szurke csikos variety the same as in 2003. The highest total fat content was given by Goleador, that is $41.81 \%$ in 2003 and $47.71 \%$ in 2005 . More than 40-percent average fat content, slightly lower than in the catalogue, was reached by the Kernal (41.53\%), Kongo reached $38.7 \%$, and the Delija hybrid reached $39.44 \%$ of fat.

Table 5: Oleic acid contents in the oil and total fat contents within the sunflower seed (Helianthus annuus L.) for the cultivars: Kernal, Kongo, Delija, Goleador and Iregi szurke csikos. Collection plantation, BF, Ljubljana, 2003.

\begin{tabular}{|l|c|c|c|c|c|c|}
\hline \multirow{2}{*}{ Cultivar } & \multicolumn{3}{|c|}{ Share of oleic acids (mass \% from total oleic acids) } & $\begin{array}{c}\text { Total } \\
\text { fat }\end{array}$ \\
\cline { 2 - 7 } & $\begin{array}{c}\text { Palmitic } \\
\text { acid } \\
\text { C } \mathbf{1 6}: \mathbf{0}\end{array}$ & $\begin{array}{c}\text { Stearic } \\
\text { acid } \\
\text { C } \mathbf{1 8}: \mathbf{0}\end{array}$ & $\begin{array}{c}\text { Oleic acid } \\
\text { C 18 : } \mathbf{1}\end{array}$ & $\begin{array}{c}\text { Lanoleic } \\
\text { acid } \\
\text { C } \mathbf{1 8}: \mathbf{2}\end{array}$ & $\begin{array}{c}\text { Linolenic } \\
\text { acid } \\
\text { C 18 : } \mathbf{3}\end{array}$ & $\begin{array}{c}\text { content } \\
\text { (\%) }\end{array}$ \\
\hline Kernal & 6.09 & 5.83 & 27.85 & 60.09 & 0.12 & 41.50 \\
\hline Kongo & 5.35 & 5.24 & 34.25 & 55.01 & 0.14 & 38.34 \\
\hline Delija & 5.77 & 4.26 & 43.21 & 46.63 & 0.12 & 38.98 \\
\hline Goleador & 4.06 & 4.09 & 77.68 & 14.03 & 0.11 & 41.81 \\
\hline Iregi s. c. & 6.33 & 5.63 & 30.58 & 57.29 & 0.16 & 33.36 \\
\hline
\end{tabular}

For the Goleador hybrid the content of oleic acid in the years $2003(77.68 \%)$ and $2005(78.67 \%)$ was a little lower than expected $80 \%$ (Table 1). Semi-oleic hybrid Delija that reached $43.21 \%$ oleic acid in 2003 and $44.22 \%$ in 2005 , exceeded the 
oleic acid content obtained in the oil from the Kernal, Kongo and Iregi, where it was approximately $30 \%$.

Table 6: Content of oleic acids in the oil and total fat content in sunflower seed (Helianthus annuus L.) for the cultivars: Kernal, Kongo, Delija, Goleador and Iregi szurke csikos from the crop in 2005. Collection plantation, BF, Ljubljana, 2005.

\begin{tabular}{|c|c|c|c|c|c|c|}
\hline \multirow[t]{2}{*}{ Cultivar } & \multicolumn{5}{|c|}{ Share of oleic acids (mass \% from total oleic acids) } & \multirow{2}{*}{$\begin{array}{c}\text { Total } \\
\text { fat } \\
\text { content } \\
(\%)\end{array}$} \\
\hline & $\begin{array}{c}\text { Palmitic } \\
\text { acid } \\
\text { C } 16: 0\end{array}$ & $\begin{array}{c}\text { Stearic } \\
\text { acid } \\
\text { C } 18: 0\end{array}$ & $\begin{array}{c}\text { Oleic acid } \\
\text { C } 18: 1\end{array}$ & $\begin{array}{c}\text { Linoleic } \\
\text { acid } \\
\text { C } 18: 2\end{array}$ & $\begin{array}{c}\text { Linolenic } \\
\text { acid } \\
\text { C } 18: 3\end{array}$ & \\
\hline Kernal & 6.23 & 5.73 & 28.83 & 59.02 & 0.18 & 41.57 \\
\hline Kongo & 4.37 & 5.00 & 35.17 & 55.31 & 0.13 & 39.20 \\
\hline Delija & 5.06 & 5.23 & 44.22 & 45.33 & 0.15 & 39.90 \\
\hline Goleador & 4.07 & 4.10 & 78.67 & 13.02 & 0.14 & 44.71 \\
\hline Iregi s. c. & 6.22 & 5.45 & 29.84 & 58.27 & 0.20 & 32.99 \\
\hline
\end{tabular}

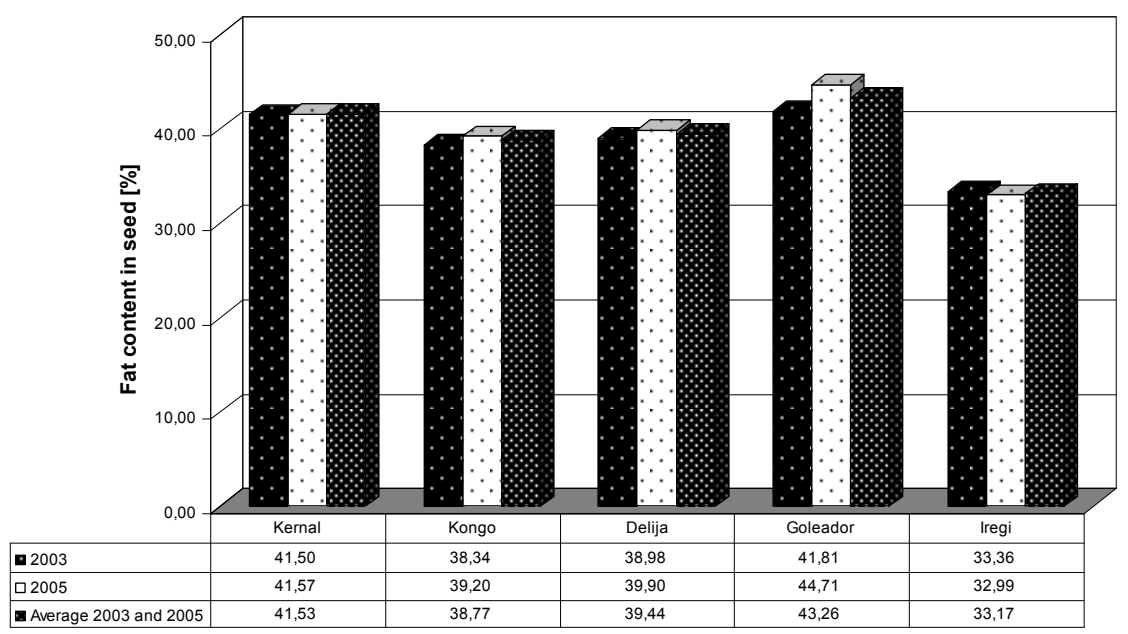

Picture 4: Total fat content in sunflower seed (Helianthus annuus L.) for the cultivars: Kernal, Kongo, Delija, Goleador and Iregi szurke csikos. Collection plantation, BF, Ljubljana, 2003 and 2005.

\section{CONCLUSIONS}

Since in the past decades in Slovenia we have abolished the production of numerous crops, sunflower among them, farmers are left without suitable expert support, covering the information on cultivar characteristics and instructions for agricultural technical measures. Reproaches from the previous years that the experts failed should not be repeated, now is time for cooperation, based on the common testing of suitability of crops and cultivars for the growing conditions on farm fields and in field trials in scientific institutions. 
Results of the field trials with five sunflower cultivars in the period between 2002 and 2006 show important differences between the cultivars in their growing period, plant height, size of the crop, fat content and fatty acid composition. We also detected differences between years and deviations from economically significant properties, determined under different growing conditions.

The expected yield of the hybrids - four tons per hectare, was most approached by the Kernal and Kongo hybrids with the exception of the year 2004, when their crop was half lower, but still also in that year - higher than the crop given by two other hybrids and from the Iregi szurke csikos variety. Not only data for their fertility, but also their fat content of the seed is higher than the values given by the Iregi szurke csikos variety, therefore they are more suitable for economic sowing, either for the bird feed or for the oil pressing.

In spite of the low yield of seed $-2.3 \mathrm{t} / \mathrm{ha}$, the Goleador hybrid with average oleic acid content in the oil in the amount of $77.68 \%$ in the year 2003 and 78.69 in the year 2005 has a good potential, also for Slovene producers of cold pressed oil and consumers of organic foods. Also semi-oleic hybrid Delija with the average 40percent oleic acid content in the oil and with approximate 40-percent oil content in the seed has all characteristics suitable for production of cold pressed oil, but its yield is one time smaller than the yield given by the Kernal and Kongo hybrids. Since so far the Delija hybrid is not registered in any of the EU member states, we would have to register it here before sowing.

It is our opinion that the sowing of larger quantity of sunflower into the crop rotation has an important impact on widening the usual and very narrow crop rotation (wheat-corn), on the other side by using the sunflower, we can increase the share of root crops, such as potato, which covers less than 6000 hectares and sugar beet, which could no longer be found on Slovene fields after the closing of the Ormož Sugar factory.

\section{LITERATURE}

Bogataj, A. 2007. Vpliv roka setve na pridelek petih izbranih hibridov sončnice (Helianthus annuus L.) na laboratorijskem polju Biotehniške fakultete. Diplomsko delo, Univerza v Ljubljani, Biotehniška fakulteta (mentorica: Darja Kocjan Ačko), Oktober 2007, 32 str.

Garces, R., M. Mancha 1993. One-Step Lipid Extraction and oleic Acid Methyl Esters Preparation from Fresh plant Tissues. Analitical Biochemistry 211, 139-143.

Geisler, G. 1980. Sonnenblume. V: Pflanzenbau. - Paul Parey, Berlin, Hamburg, str. 358-359.

Jereb, A. 2004. Morfološke in nekatere gospodarsko pomembne lastnosti sončnic (Helianthus annuus L.) na laboratorijskem polju Biotehniške fakultete. Diplomsko delo, Univerza v Ljubljani, Biotehniška fakulteta (mentorica: Darja Kocjan Ačko), September 2004, 44 str.

Kocjan Ačko, D. 1999. Sončnica. V: Pozabljene poljščine. ČZD Kmečki glas, 143-156.

Kocjan Ačko, D. 2007. Brez setve ni žetve. V: Kmečki glas, proga revije Sodobno kmetijstvo 
58 Acta agriculturae Slovenica, 91 - 1, maj 2008

Mandekić, V. 1942. Suncokret. V: Uljevito i predivno bilje. - Jeronimska knjižnica. Hrvaško književno društvo sv. Jeronima, 2-30.

Sadar, V. 1951. Sončnica. V: Oljnice, korenovke, predivnice in hmelj. - Založba Kmečka knjiga, Ljubljana, 292-295.

Stanaćev, S. 1982. Suncokret. V: Gajenje industrijskih biljaka. - Biblioteka Zelena sveska, Novi Sad, str. 41-64.

Škorić, D. 1989. Suncokret. Beograd, Nolit: 636 str.

Tajnšek, T. 1987. Sončnica. V: Ogrščica in sončnica. - ČZD Kmečki glas: 76-97. 